\title{
Detection of Opportunistic Fungus Pneumocystis jirovecii Major Surface Glycoprotein (MSG) gene in HIV-AIDS Patients with Pneumoniae in Jakarta
}

\author{
Conny Riana Tjampakasari ${ }^{1}$, Andi Yasmon ${ }^{1}$, Agus Sjahrurachman ${ }^{1}$, and \\ Samsuridjal Djauzi ${ }^{2}$ \\ ${ }^{1}$ Department of Microbiology, Faculty of Medicine, University of Indonesia \\ ${ }^{2}$ Department of Allergy Immunology, RSCM, Faculty of Medicine, University of Indonesia
}

\section{Abstract}

Pneumocystis jirovecii is known to cause opportunistic infections in the lower respiratory tract in individuals with low immune systems, especially patient with HIV infection. The prevalence of $P$. jirovecii pneumonia (PjP) in various countries show varying numbers. In Indonesia, HIV cases continue to rise. However, the data in Indonesia concerning the case of PjP is very limited. Until now the prevalence of PjP in Indonesia is only based

Corresponding Author: Conny Riana Tjampakasari connyrianat@yahoo.com

Received: 1 February 2020 Accepted: 8 February 2020 Published: 16 February 2020

Publishing services provided by Knowledge E

(c) Conny Riana Tjampakasari et al. This article is distributed under the terms of the Creative Commons Attribution License, which permits unrestricted use and redistribution provided that the original author and source are credited.

Selection and Peer-review under the responsibility of the IC-BIOLIS Conference Committee. on clinical symptoms of the patient. Currently, diagnosis of PjP relies on microscopic examination. The disadvantage of this examination is not easy to do and has a high negative predictive value. Thus, this study was conducted to develop a molecular test to diagnose PjP infection in HIV-AIDS suspected pneumonia. Molecular diagnostic test aimed for Major Surface Glycoprotein (MSG) gene of $P$. jirovecii detection was done through real-time PCR against 100 sputum samples. Demographic data show that the prevalence of PjP infection in HIV-AIDS suspected pneumonia patients in Jakarta is $20.0 \%$, male $75 \%$ within $31-40$ y.o (35\%), dominant (80\%) from patients with $C D^{4+}$ T-lymphocytes of 200-349 cells/ $\mu \mathrm{L}$. Molecular real-time PCR methods were shown to give five times sensitivity higher than Giemsa stain.

Keywords: P. jirovecii, HIV, real-time PCR

\section{Introduction}

Pneumocystis jirovecii is known to cause opportunistic infections in the lower respiratory tract in individuals with weakened immune systems, especially patients with infection $\mathrm{HIV}^{1}$. Individuals with an intact immune system will control the primary infection and the microorganisms will remain latent in the lung. Disease will occur when the immune system is disrupted or deficient. In this case, it is possible to find the cause of clinical pneumonia in respiratory tract ${ }^{2,3}$. 
International epidemiologic survey showed that pneumonia distributed worldwide with antibody prevalence varies among different geographical areas and can attack human at various ages ${ }^{4,5}$. The prevalence of $\mathrm{PjP}$ in various countries showed varying numbers. In Indonesia, HIV cases continue to rise. However, the data in Indonesia concerning the case of the PjP is very limited, until now the prevalence of PjP in Indonesia is only based on clinical symptoms of patients in the amount of $13.4 \%$ as reported by Lydia et al. (2009). In the same year at other hospitals in Indonesia (RS Persahabatan and the RSCM), $14.55 \%$ of the PjP was found in 55 patients studied. The figure is lower than the state other countries ${ }^{6,7}$.

Inadequate diagnostic facilities cause PjP incidence data in Indonesia is not known with certainty. Currently in Indonesia, raw diagnostic standard for the diagnosis of PjP is not available, resulting in undetected cases. This can occur because, despite the many studies done, successful breeding of Pneumocystis jirovecii is very limited, so that its life cycle is not yet fully understood ${ }^{8}$.

Until now, diagnosis of PjP relies on microscopic examination of respiratory specimens such as bronchial washings fluid (bronchoalveolar lavage/BAL), sputum induction or sputum $^{8}$. The disadvantage of this examination is not easy to do and has a high negative predictive value. $^{9}$

This study conducted real-time PCR detection for gene Major Surface Glycoprotein (MSG) as a rapid diagnosis of infection with $P$. jirovecii. Hopefully this research can be applied to diagnose infection with $P$. jirovecii thereby assisting in the management of HIV patients with pneumonia symptoms quickly and accurately.

\section{Methods}

Hundreds of sputum that have been obtained is mixed with ditiotreitol (Sputolysin; Behring Diagnostics), and vortexed for 30 seconds (Vortex Genie 2, Scientific Industries), followed by incubation in the incubator (Thermo Electron Corporation) with $35-37^{\circ} \mathrm{C}$ temperature for 15 minutes. After incubation, the specimen is mixed with phosphate buffered saline $(\mathrm{pH}$ 7.4) until the turbidity is equivalent to $0.5 \mathrm{Mc}$. Farland. The mixture was then vortexed for another 15 seconds. Furthermore specimen was centrifuged at 3000 RPM (Universal $320 \mathrm{R}$, Hettich Zentrifugen) at a temperature of $25^{\circ} \mathrm{C}$ for 5 minutes. The supernatant was discarded while the pellet $(1 \mathrm{~mL})$ was used for coloring Giemsa ${ }^{10,11,12,13}$.

For real-time PCR test, the pellets were then centrifuged with a speed of 12000 RPM (Sorvall Biofuge Primo) at a temperature of $25^{\circ} \mathrm{C}$ for 5 minutes. Furthermore, the 
supernatant was discarded while the pellet as genomic DNA stored in a refrigerator at a temperature of $-80^{\circ} \mathrm{C}$ to be used for the analisys ${ }^{14,15,16}$.

\subsection{Test microscopy with Giemsa Staining}

Staining was done by using Giemsa staining Modification ${ }^{17}$. Microscopic tests were done by spreading the suspension of pellets above the glass pedestal to form a thin layer. This was then dried through aeration in open air. Following this, 95\% ethyl alcohol was poured until it covered the entire surface of the preparation, and this was then left to dry. Furthermore Sulphation reagent is dripped onto the preparation and allowed to stand for 10 minutes, then washed with running water for 5 minutes. After this, the preparations were stained with Giemsa $10 \%$ for 30 minutes, before being washed with water and allowed to dry in the air. After drying, a drop of emersion oil was dripped on the preparation and then viewed under microscope with magnification of $10 \times 100^{18}$.

\subsection{DNA extraction Pneumocystis jirovecii}

Extraction of specimens was performed in accordance with the procedures on extraction kit QIAmp DNA Mini Kit (Qiagen) as follows: Pellet from the processing of specimens was removed from the refrigerator to a temperature corresponding to room temperature. Furthermore $20 \mathrm{~mL}$ of Qiagen protease (proteinase $\mathrm{K}$ ) and $180 \mathrm{~mL}$ of aqueous Tissue Lysis buffer (ATL) was added into pellets, homogenized using a vortex (Maxi Mix II) for 15 seconds and incubated at $56^{\circ} \mathrm{C}$ overnight for the lysis of cells. After 24 hours, the sample was centrifuged at a speed of 12000 RPM for 15 seconds to remove fluid around the tube eppendorf. Then added to $200 \mathrm{~mL}$ of Aqueous Lysis buffer (AL), hereinafter homogenize using a vortex for 15 seconds, and incubation at temperature of $70^{\circ} \mathrm{C}$ for 10 minutes. The next step centrifugation at a speed of 12000 RPM for 15 seconds to remove fluid tube wall, followed by addition of $200 \mathrm{~mL}$ of ethanol (96-100\%). The specimen was then homogenized using a vortex for 15 seconds and re-centrifuged with the speed of 12000 RPM for 15 seconds. The next step was to move $600 \mathrm{~mL}$ of solution to QIAmp DNA mini spin column without wetting the rim, and centrifuged at 12000 RPM for 1 minute. The QIAmp DNA mini spin column was then transferred to a clean collection tube and added $500 \mathrm{~mL}$ of Aqueous Washing buffer 1 (AW1), followed by centrifugation at 12000 RPM for 1 minute. Furthermore, DNA QIAmp mini spin column was transferred back to the new receiver tube and have the filtered receiver tube removed. After this, a $500 \mathrm{~mL}$ of Aqueous Washing buffer 2 (AW 2) was added and then re-centrifuged 
(12000 RPM) for 3 minutes. Next, the collected filtrate was discarded, and DNA QIAmp mini spin tube was put back in the same tube. After this, centrifugation was re-performed at 12000 RPM for 1 minute. After this, the QIAmp DNA mini tube was placed on clean microsentrifuge $1.5 \mathrm{ml}$ tube, followed by adding $70 \mathrm{~mL}$ of aqueous elution buffer (AE) and incubated at room temperature for 5 minutes, then re-centrifuged $(12,000$ RPM) for 2 minutes. In the final step, the filtrate was collected in microcentrifugated tubes and stored at $-35^{\circ} \mathrm{C}$ until used for the reaction real-time $\mathrm{PCR}{ }^{19,20,21}$.

\subsection{Real-time $P C R$}

Pneumocystis jirovecii in samples was detected by using kappa probe Fast qPCR Master Mix kit (Bio-Rad iCyclerTM). Primers and probes were used in this study as reported by Gupta et al (2008) ${ }^{22}$ (Table 1). The composition of the real-time PCR reaction $(20 \mu \mathrm{L})$ is a follows: 1x Kapa Fast Probe Enzyme, $0.5 \mu \mathrm{M}$ Primary (MSG forward), $0.5 \mu \mathrm{M}$ Primary (reserve MSG), $0.5 \mu \mathrm{M}$ Probe and $4 \mu \mathrm{L}$ DNA. The real-time PCR reaction was carried out using Bio-Rad iCyclerTM (Bio-Rad) with the following conditions: $95^{\circ} \mathrm{C}$ for 3 minutes (enzyme activation) and 45 cycles at $95^{\circ} \mathrm{C}$ for 15 seconds and $58{ }^{\circ} \mathrm{C}$ for 1 minute.

TABLE 1: Primer and probe sequences Pneumocystis jirovecii ${ }^{23,24}$.

\begin{tabular}{l|l|c}
\hline Primer & Sequences (5'-3') & Position \\
\hline $\begin{array}{l}\text { PjP Forward } \\
\text { PjP Reverse }\end{array}$ & CAAAAATAACAYTSACATCAACRAGG & $223-248$ \\
\hline Probe & AAATCATGAACGAAATAACCATTGC & $378-354$ \\
\hline PjP probe & Sequences & \\
\hline
\end{tabular}

\section{Results}

\subsection{Subjects demographics}

A total of $100 \mathrm{HIV}$-infected patients with pneumoniae symptoms were observed in this study. Symptoms and clinical signs found in patiens are low-grade fever, shortness of breath and non-productive cough.

Characteristics of subjects by sex, age and number of $\mathrm{CD}^{4+} \mathrm{T}$ (cell/ $\left.\mu \mathrm{L}\right)$ can be seen in Table 1. Data obtained through anamnesa and confirmatiom of the patient's medical record status. The patients consisted of 68 male and 32 female. The age range from 20-66 years-olds. Data on the number of $C D^{4+} T$ lymphocytes shows that there are 25 
TABLE 2: Subjects demographics $(n=100)$.

\begin{tabular}{|l|c|c|}
\hline \multicolumn{1}{|c|}{ Variable } & & Total \\
\hline Sex & Male & 68 \\
\hline & Female & 32 \\
\hline Age & Total & 100 \\
\hline & $20-30$ & 12 \\
\hline Number of $\mathbf{C D}^{4+}$ T lymphocytes (cell/ $\left./ \mathrm{L}\right)$ & $31-40$ & 57 \\
\hline & $41-50$ & 19 \\
\hline & $51-60$ & 9 \\
\hline & $>60$ & 3 \\
\hline & Total & 100 \\
\hline & $<50$ & 2 \\
\hline
\end{tabular}

patients with $C D^{4+} \geq 350,62$ patients with $C D^{4+}$ 200-349, 11 patients with $C D^{4+}$ 50-199 and $C^{4+}$ 50-199 as many as 2 patients.

\subsection{Detection of $P$. jirovecii using the real-time PCR method}

From 100 samples examined, 20 samples gave positive results of $P$. jirovecii. DNA amplification curves using real-time PCR can be seen in Figure 1. The figure shows that positive controls form a sigmois curve while negative controls do not form a sigmoid curve. One sample shows positive, and negative for the other.

The relationship between sex, age and $C D^{4+}$ T-lymphocyte cell with a positive realtime PCR of P. jirovecii can be seen in Table 2. The table shows that 20 positive patients was consisted of $15(75 \%)$ men and 5 (25\%) women. The predominant range of age is $31-40$ year old (30\%). Analysis of number of $\mathrm{CD}^{4+} \mathrm{T}$-lymphocyte cells showed predominantly in $\mathrm{CD}^{4+}$ T-lymphocyte cells 200-349 with 16 patients (80\%).

\subsection{Detection of P. jirovecii using Giemsa Staining}

Microscopic examination was performed with Giemsa staining modified with sulphation. We obtained 3 positive samples of $P$. jirovecii (Table 3 ). One of the samples found a 


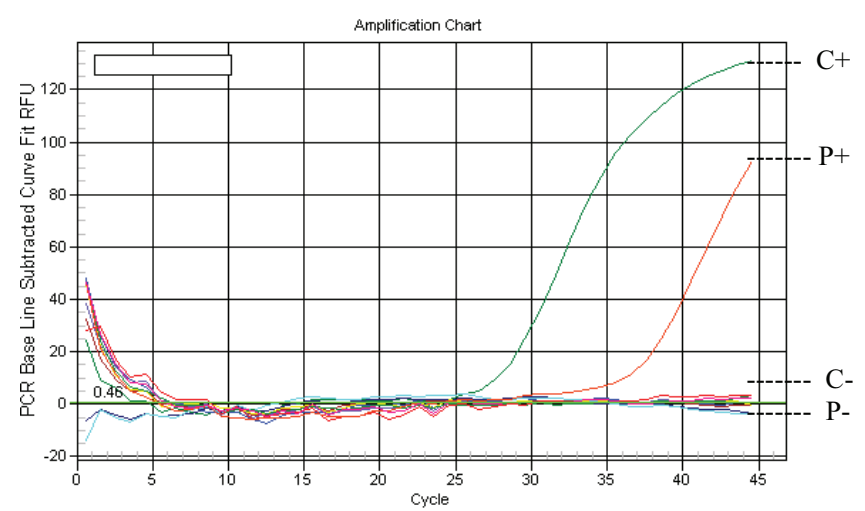

Figure 1: Example of $P$. jirovecii DNA detection results using real-time PCR. Horizontal line are real-time cycles. The vertical line is a fluorescent signal (cycle threshold/Ct). C+: positive control, C-: negative control, $\mathrm{P}+$ : positive patient, $\mathrm{P}-$ : negative patient.

TABLE 3: Demographics and characteristics of real-time PCR result.

\begin{tabular}{|c|c|c|c|c|c|}
\hline & & \multicolumn{4}{|c|}{ Real-time PCR result } \\
\hline \multicolumn{2}{|c|}{ Variable } & \multicolumn{2}{|c|}{ Negative $(n=80)$} & \multicolumn{2}{|c|}{ Positive $(n=20)$} \\
\hline & & Total & (\%) & Total & (\%) \\
\hline \multirow[t]{3}{*}{ Sex } & Male & 53 & $(66.2)$ & 15 & (75.0) \\
\hline & Woman & 27 & (33.8) & 5 & $(25.0)$ \\
\hline & Total & 80 & $(100.0)$ & 20 & $(100.0)$ \\
\hline \multirow{9}{*}{$\begin{array}{l}\text { Age Number of } \mathrm{CD}^{4+} \mathbf{T} \\
\text { lymphocytes }\end{array}$} & $20-30$ & 10 & $(12.5)$ & 2 & $(10.0)$ \\
\hline & $31-40$ & 50 & $(62.5)$ & 7 & (35.0) \\
\hline & $41-50$ & 13 & $(16.2)$ & 6 & (30.0) \\
\hline & $51-60$ & 5 & $(6.2)$ & 4 & (20.0) \\
\hline & $>60$ & 2 & (2.5) & 1 & $(5.0)$ \\
\hline & Total & 80 & $(100.0)$ & 20 & (100.0) \\
\hline & $<50$ & 1 & $(1.2)$ & 1 & $(5.0)$ \\
\hline & $50-199$ & 10 & $(12.5)$ & 1 & $(5.0)$ \\
\hline & $200-349$ & 46 & (57.5) & 16 & $(80.0)$ \\
\hline \multirow[t]{2}{*}{ (cell/ $/ \mu L)$} & $\geq 350$ & 23 & $(28.8)$ & 2 & (10.0) \\
\hline & Total & 80 & $(100.0)$ & 20 & (100.0) \\
\hline
\end{tabular}

cyst form of this microorganism (Figure 2). Table 3 shows 2 (66,66\%) male patients was positive Giemsa staining. The age range 31-40, 41-50 and 51-60 years-old occupy proportionately, with each age group at $33,33 \%$. Analysis of number of $C D^{4+}$ T-lymphocyte cells showed predominantly in CD $^{4+}$ T-lymphocyte cells 200-349 (100\%). 
TABLE 4: Demographics and characteristics of Giemsa staining.

\begin{tabular}{|c|c|c|c|c|c|}
\hline & & \multicolumn{4}{|c|}{ Giemsa staining } \\
\hline \multicolumn{2}{|c|}{ Variable } & \multicolumn{2}{|c|}{ Negative $(n=97)$} & \multicolumn{2}{|c|}{ Positive ( $n=3$ ) } \\
\hline & & Jumlah & (\%) & Jumlah & (\%) \\
\hline \multirow[t]{3}{*}{ Sex } & Male & 66 & (68.0) & 2 & $(66,66)$ \\
\hline & Female & 31 & (32.0) & 1 & $(33,33)$ \\
\hline & Total & 97 & (100.0) & 3 & $(100.0)$ \\
\hline \multirow[t]{6}{*}{ Age } & $20-30$ & 12 & (12.4) & 0 & $(0.00)$ \\
\hline & $31-40$ & 56 & $(57.7)$ & 1 & (33.3) \\
\hline & $41-50$ & 18 & (18.6) & 1 & (33.3) \\
\hline & $51-60$ & 8 & (8.20) & 1 & (33.3) \\
\hline & $>60$ & 3 & (3.10) & 0 & $(0.00)$ \\
\hline & Total & 97 & (100.0) & 3 & $(100.0)$ \\
\hline \multirow{5}{*}{$\begin{array}{l}\text { Number of } C D^{4+} T \\
\text { lymphocytes (cell/ } \mu \mathrm{L})\end{array}$} & $<50$ & 2 & $(2.10)$ & 0 & $(0.00)$ \\
\hline & 50-199 & 11 & (11.3) & 0 & $(0.00)$ \\
\hline & $200-349$ & 59 & $(60.80$ & 3 & (100.0) \\
\hline & $\geq 350$ & 25 & $(25.8)$ & 0 & $(0.00)$ \\
\hline & Total & 7 & (100.0) & & $(100.0)$ \\
\hline
\end{tabular}
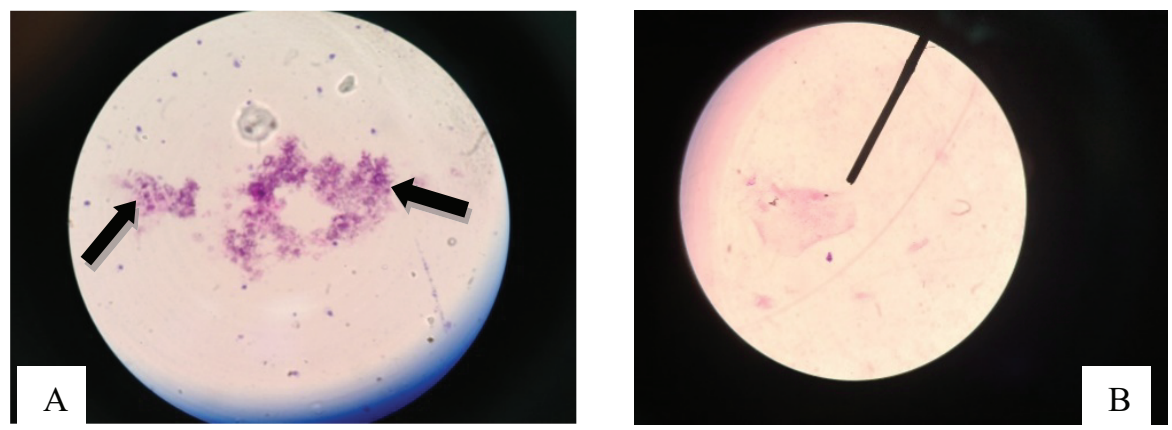

Figure 2: Giemsa staining results were modified with sulphation. A. Microscopic results of positive Giemsa. The arrow on the left shows the cyst stage, while the arrow on the right shows the trophozoite stage with a magnification of 1000x. B. Microscopic results of negative Giemsa.

\subsection{Comparison of real-time PCR and Giemsa microscopic}

Table 4 shows 3 out of 100 samples gave positive results both real-time PCR and Giemsa staining (15\%). Seventeen samples that were detected as negative by microscopic gave positive result on real-time PCR (17\%). This result shows that real-time PCR increases the positive value more than 5 times compared to microscopic test. Another 80 samples gave the same (negative) results both with real-time PCR and Giemsa staining. 
TABLE 5: Comparison of real-time PCR and Giemsa microscopic.

\begin{tabular}{|c|c|c|c|c|c|c|}
\hline \multicolumn{9}{|c|}{ Total (\%) Specimen } \\
\hline P. jirovecii & rPCR+ M+ & rPCR+ M- & rPCR- M- & rPCR- M+ & Total M+ & $\begin{array}{c}\text { Total rPCR+ } \\
\text { PCR+ }\end{array}$ \\
\hline & $3(15 \%)$ & $17(17 \%)$ & $80(50 \%)$ & $0(0 \%)$ & $3(15 \%)$ & $20(20 \%)$ \\
\hline
\end{tabular}

rPCR: real-time PCR, -: negative

M: microscopic test, +: positive

\section{Discussion}

\subsection{Subject Characteristics}

The real-time PCR test results show that the infection rate of $P$. jirovecii is $20 \%$. Our study provides the most recent data for the prevalence of PjP infections in Indonesia. Until now the data reported only based on patient clinical symptoms which is $14,45 \%$ as reported in several hospitals in Jakarta ${ }^{10}$. Compared to other countries in Southeast Asia, infection of $P$. jirovecii obtained are lower but close to neighboring Malaysia which is $22.7 \%$, 5,9 . The differences in infection rates can be caused by host immunity infection, various diagnostic facilities and different geographical factors.

Male occupies a dominant position compared to women with a percentage of $75 \%$ and $25 \%$, respectively. The age range of patients is between $20-66$ years. These results indicate differences compared with The Republic of Indonesia Ministry of Health 2013 , that the highest percentage of cases was found in the range age of 25-49 years $(70.4 \%)$ which is the most productive age group ${ }^{25,26}$. This age differences needs to be further examined as this study provide evidence of detection in both early and old age.

Based on the number of $\mathrm{CD}^{4+} \mathrm{T}$ - lymphocytes, the range of 200-349 occupies the highest percentage (80\%). This is an interesting finding in this study beacuse many other studies mentioned that Pneumocystis pneumonia generally occurs in HIV patients with $\mathrm{CD}^{4+}$ T-lymphocytes $<200$ cells/ $\mu \mathrm{L}^{27,28,29,30,31}$, whereas in this study, the number $\mathrm{CD}^{4+}$ T-lymphocytes did not affect the presence of $P$ jirovecii in patients. $P$ jirovecii can be obtained from birth and occur through reactivation of altent infections when the immune system decrease. Several researchers have revealed that $P$. jirovecii transmission can be obtained from the enviroment, from infected people, and can also be transmitted from someone who has $P$. jirovecii colonization ${ }^{32,33,34}$.

This study revealed thet even though anti-retroviral (ARV) treatment caused an increase in $\mathrm{CD}^{4+}$ T-lymphocytes levels, $P$. jirovecii remained an important opportunistic 
infection in HIV-AIDS patients such as stated by Moris and Norris (2012) and Khalife et al. $(2015)^{6,7}$.

Giemsa staining that was modified using sulphation was found to improve the visualization of cyst shapes that was not detected in conventional Giemsa. This research has succeeded in getting a cyst shape in 1 of the 3 positive samples. Addition of sulphation which is addition of a mixture of sulfuric acid and glacial acetic acid before staining helped the Giemsa polychrome dye to react to opening the fungal cell wall and absorbsing dye so that the cyst can be clearly seen.

In terms of patients' gender distribution, male was found to be higher than female, with $66.66 \%$ and $33.33 \%$, respectively. Distribution of patient's age was found to be proportionate, with $33.33 \%$ for each age range of 31-40, $41-50$ and 51-60 years old. Analysis of the $\mathrm{CD}^{4+} \mathrm{T}$-lymphocytes showed that all patients were in the range of 200349 cells/ $\mu \mathrm{L}$.

\subsection{Comparison of real-time PCR and Giemsa staining}

Three samples gave positive results both on microscopic and real-time PCR, whereas 17 samples that were stated negative by microscope, gave positive results on real-time PCR. A total of 80 samples gave the same negative results, both with microscopic and real-time PCR.

Analysis of the results shows that real-time PCR increases of positive by more than 5 times compared to microscopic tests. This results are in accordance with research conducted by Pierre et al (2004), his research shows real-time PCR increases sensitivity by up to $60 \%$ compared to Giemsa staining. Tia et al (2011) and Florence et al (2014) showed real-time PCR increased positive results compared to microscopy, respectively at $41 \%$ and $19 \%{ }^{35,36,37}$. Major surface glycoproteins were chosen as targets because they have the most varied sequences found on the surface of fungal cells and are sustainable. Additionally, the MSG gene can increase sensitivity so that it is used by many researchers for detection ${ }^{38,39,40,41}$.

\section{Conclusion}

The developed real-time PCR detection was able to provide better diagnostic value than Giemsa staining. Demographically, the prevalence of $P$. jirovecii in HIV-AIDS with pneumonia in Jakarta reached $20 \%$, dominant in the range of $\mathrm{CD}^{4+}$ T-lymphocytes 200-349 cells/ $\mu \mathrm{L}$. 


\section{References}

[1] James RS, Charles BB, Robert FM, and Ann EW. A new name (Pneumocystis jirovecii) for Pneumocystis from humans. Emerg Infect Dis. 2002;8(9):891-6

[2] Nimri LF, Moura, Moura INS, Huang L, Rio CD, Duchin JS, Dotson EM and Beard CB. Genetic Diversity of Pneumocystis carinii $f$. $s p$. hominis based on variations in nucleotide sequences of internal transcribed spacers of rRNA Genes. J Clin Microbiol. 2002;40(4):1146-51

[3] Kwon Chung KJ and Bennet JE. Medical mycology. Philadelphia: Lea \& Febriger; 1992.p.369-76

[4] Miller RF, Huang L and Walzer PD. Pneumocystis Pneumonia associated with human immunodeficiency virus. Clin Chest Med. 2013;34: 356-61

[5] Morris A, Wei K, Afshar K and Huang L. Epidemiology and clinical significance of Pneumocystis colonization. J Infect Dis. 2008; 197:10-7

[6] Morris A and Norris KA. Colonization by Pneumocystis jirovecii and its role in disease. J ASM Org Am Soc Microbiol. 2012;25(2): 297-317

[7] Khalife S, Aliouat EM, Aliouat CM, Gantois N, Devos P, Mallat H, Del-Cas E, Dobbousi F, Hamze M and Realle E. First data on Pneumocystis jirovecii colonization in patients with respiratory diseases in north Lebanon. N Microb N Infect. July 2015;6:11-4

[8] Han K, Mra R, Saw H and Naing W. Pneumocustis carinii infection among Human Immunodeficiency Virus infected Myanmar pasient. Parasitology Research Division, Departmen of Medical Research Myanmar. South Asian J Trop Med Publ Health. 2011;48:103-5

[9] Pohan HT. Oppurtunistic infection of HIV-infected/AIDS patients in Indonesia: problems and challenge. Acta Med Indon. 2006;38:169-73

[10] Rozaliyani A. Karakteristik klinis, radiologis dan laboratoris pneumonia Pneumocystis pada pasien AIDS dengan gejala pneumonia di beberapa rumah sakit di Jakarta. Jakarta: Medical Research Unit FKUI; 2009.h. 22-51

[11] Beard CB, Carter JL, Keely SP, Huang L, Pieniazek NJ, Moura IN, Roberts JM, Hightower AW, Bens MS, Freeman AR, Lee S, Stringer JR, Duchin JS, del Rio C, Rimland D, Baughman RP, Levy DA, Dietz VJ, Simon P and Navin TR. Genetic variation in Pneumocystis carinii isolates from different geographicregions: amplications for transmission. Emerg Infect Dis. 2000;6:65--272

[12] Heelan JS and Ingensol FW. Essentials of human parasitology. United States: Delmar; 2002.p.130-1 
[13] Murray PR, Rosenthal KS, Kobayashi GS, Knapp JS and Rice RJ. Manual of clinical microbiology, $6^{\text {th }}$ ed. Washington: DC. ASM Press; 1995. p.432-36

[14] Knap and Pfaller MA. Medical microbiology, $4^{\text {th }}$ Ed. USA: Mosby, Missoury; 2002.p.162-66

[15] Robert V, Theodore J. Kottom, Joseph E. Standing and Andrew H. "Limper" vitronectin and fibronectin function as glucan binding proteins augmenting macrophage responses to Pneumocystis carinii. Am J Resp Cell Mol Biol. 2001;25(2):203-211

[16] Krajicek BJ, Limper AH and Thomas CF Jr. Advances and the biology, pathogenesis and identification of Pneumocystis pneumonia. Curr Opin Pulm Med. 2008; 14:228

[17] Tsolaki AG and Miller RF. Genetic diversity at the internal transcribed spacers regions of the rRNA operon among isolates of Pneumocystis carinii from AIDS patients with recurrent pneumonia. J Infect Dis. 1996: 324-31

[18] Esteves F, Gaspar J, Marques T, Leite R, Antunes F, Mansinho K and Matos O. Identification of relevant single-nucleotide polymorphisms in Pneumocystis jiroveci: relationship with clinical data. Clin Microbiol Infect. 2010;16: 878-84.

[19] Meneau I, Sanglard D, Bille J and Hauser MP. Pneumocystis jirovecii dihydropteroate synthase polymorphisms confer resistance to sulfadoxine and sulfanilamide in Saccharomyces cerevisiae. Antimicrob Agents Chemo. 2004;7: 2610-6

[20] Valerio A, Tronconi E, Mazza F, Fantoni G and Atzori C. Genotyping of Pneumocystis jirovecii pneumonia in Italian AIDS patients: Clinical outcome is influenced by dihydropteroate synthase and not by internal transcribed spacer genotype. J Acquir Immune Defic Syndr. 2007;45(5): 521-8

[21] Jarboui MA, Mseddi F, Sellami A, Makni F and Ayadi A. Genetic diversity of Pneumocystis jirovecii strains based on sequence variation of different DNA region. Med Mycol. 2013;51: 561--7

[22] Brown HW and Neva FA. Basic clinical parasitology. United States of America: Appleton Century Crofts;1983.p.76-7

[23] Marijke JV, Vera EJK, Catherin AB, Walther NKA van Mook and Catharina FML. Molecular epidemiology of Pneumocystis jirovecii in human immunodeficiency viruspositive and -negative immunocompromised patients in The Netherlands. J Med Microbiol. 2014;63:1294--1302. DOI 10.1099/jmm.0.076257-0

[24] Dimonte S, Berrilli F, D'Orazi C, D'Alfonso R, Placco F, Bordi E, Perno CF and Di Cave. Molecular analysis based on mtLSU-rRNA and DHPS sequences of Pneumocystis jirovecii from immunocompromised and immunocompetent patients in Italy. Inf Gen Evol. 2013;14:68--72 
[25] Kementrian Kesehatan RI. Data HIV AIDS di Indonesia. 2015.

[26] Kementerian Kesehatan Republik Indonesia Direktorat Jendral Penyehatan Lingkungan dan Pengendalian Penyakit. Laporan perkembangan HIV-AIDS triwulan 4 tahun 2013.

[27] Pneumonia Komuniti. Pedoman diagnosis dan penatalaksanaan di Indonesia. Perhimpunan Dokter Paru Indonesia. 2003

[28] Yunihastuti E, Djauzi S dan Zubairi D. Infeksi oportunistik pada AIDS. Jakarta: Balai penerbit FKUl;2005,h.1-78.

[29] Agustina DR, Efiyanti C, Yunihastuti E, Ujainah A, Rozaliyani A. Diagnosis dan tata taksana Pneumocystis carinii Pneumonia (PCP)/Pneumocystis jirovecii Pneumonia pada pasien HIV: Sebuah Laporan Kasus. Jurnal Penyakit Dalam Indon. 2017; 4(4):209-13.

[30] Charles FT, Andrew HL. 2008. Pneumocystis Pneumonia. The New Eng J Med. 2008;350: 2487-98.

[31] World Health Organization. WHO case definitions of HIV for surveillance and revised clinical staging and immunoligical classification of HIV-related disease in adults and children. WHO press; 2006.p.1-38.

[32] Robert GF, Belaz S, Revest M Tattevin P, Jouneau S and Decaux O. Diagnosis of Pneumocystis jirovecii pneumonia in immunocompromised patients by real-time PCR: a 4-year prospective study. J Clin Microbiol. 2014;52(9): 3370

[33] Rodriguez YDA, Wissmann G, Muller AL, Pederiva MA, Brum MC, and Brackmann RL. Pneumocystis jirovecii pneumonia in developing countries. J Par.2011;18(3): 219-228

[34] Meja R, Laetittia V, Patrick T, Aimable N, Rene PG and Philippe MH. Pneumocystis jirovecii genotype associated with increased death rate of HIV-infected patients with pneumonia. Emerg Infect Dis.2013;19:21-8

[35] Tia T, Putapotntip C, Kosuwin, R, Kongpolprom, N, Kawkitinarong, K and Jongwitiwes S. A Highly sensitivity novel PCR assay for detection of Pnemocystis jirovecii DNA in bronchoalveolar lavage specimens from immunocompromised patients. Original Articles. Mycology. Clin Microbiol Infect. 2011:589-603

[36] Pierre F, Bahrie B, Fabrice D, Helene R, Céline C, Jamal H, Frederic L and Roger TMS. Comparison between real-time PCR, conventional PCR and different staining techniques for diagnosing Pneumocystis jirovecii pneumonia from bronchoalveolar lavage specimens. J Med Microbiol. 2004; 53: 603--7

[37] Florence RG, Sorya B, Matthieu R, Pierre T, Stéphane J, Olivier DSC, Yves LT and Jean-Pierre G. Diagnosis of Pneumocystis jirovecii pneumonia in 
immunocompromised patients by real-time PCR: a 4-year prospective study. J Clin Microbiol. 2014;52(9): 3370-6

[38] Gupta R, Mirdha BR, Guleria R, Mohan A, Kabra SK, Kumar L, Agarwal SK and Luthra $K$. Use of different primer sequence smplification by polymerase chain reaction for identification of Pneumocystis jirovecii in clinical samples. Ind J Chest Dis All Sci. 2008;50: 321-7

[39] Muhlethaler K, Bogil SK, Wasmer S, Von Garnier C, Dumont P, Rauch A, Muhlemann $K$ and Garzoni C. Quantitative PCR to diagnose pneumocystis pneumonia in immunocompromised non HIV patients. Europ Resp J. 2002; 29(4): 971-8

[40] Francoise B, Odile C, Francoise F, Catherine C, Jean Mar C and Stepahnie B. Clinical significance of quantifing Pneumocystis jirovecii DNA by using real time PCR in bronchoalveolar lavage fluid from immunocompromised patients. J Clin Microbiol. 2012;509(2): 227-31

[41] Singh S, Mirdha BR, Singh P, Guilera R, Mohan JA, Agarwal SK, Kabra SK and Pandey RM. Quantitative real time PCR assay for differentiation between pneumocystis pneumonia and pneumocystis colonization. Intern J Med Clin Res. 2014;5(1):28594 